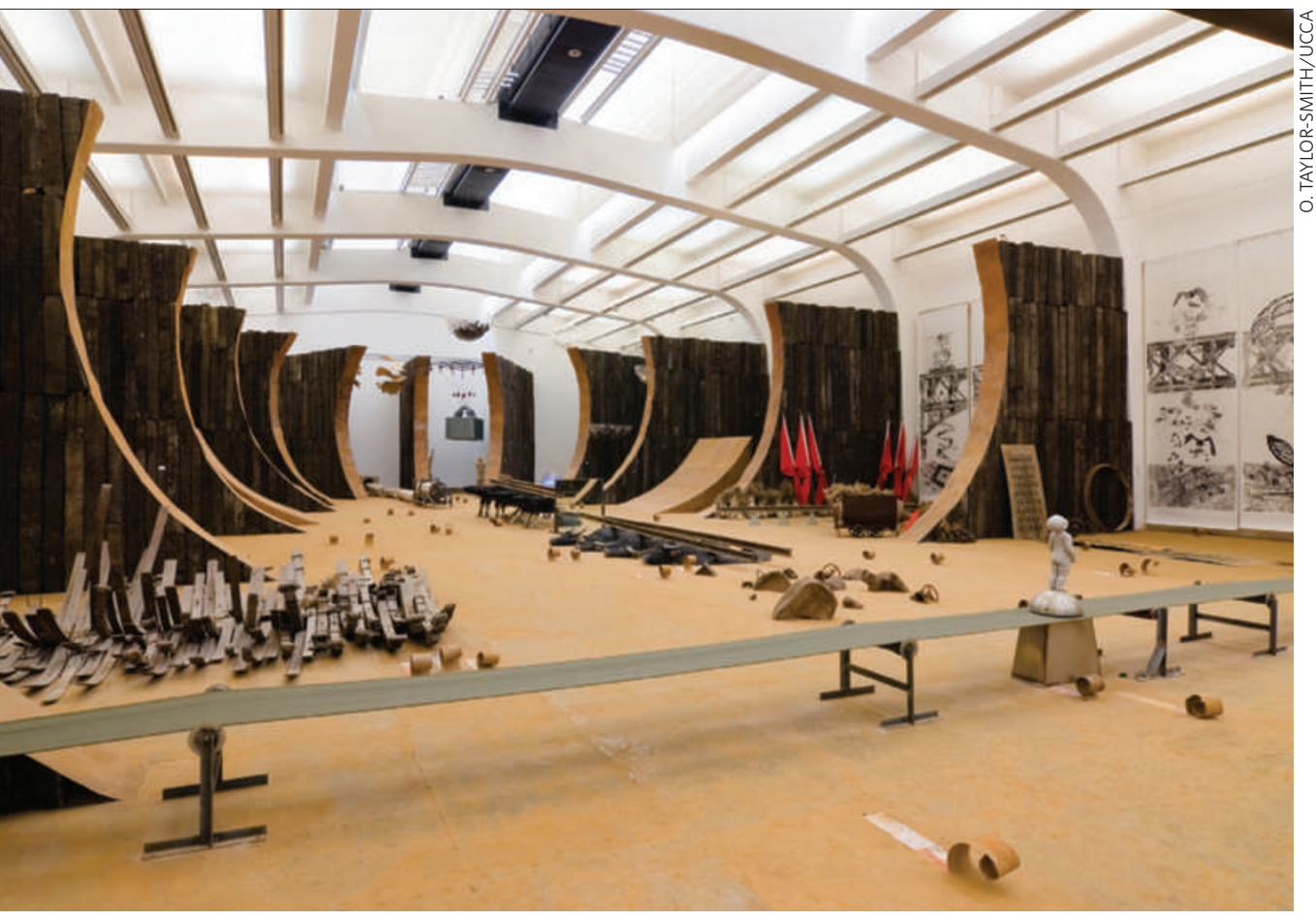

\title{
Industrial strength, corroded
}

Qiu Zhijie: Breaking Through the Ice Ullens Center for Contemporary Art, Beijing

Until 25 May 2009

Stepping into Qiu Zhijie's solo exhibition Breaking Through the Ice at the Ullens Center for Contemporary Art in Beijing is like embarking on an ill-fated journey. Through installations, sculptures and ink paintings, the artist questions China's obsession with grand projects of modernization.

In The Sinking Giant, an enormous, rusty ship's bow tilts upwards from a sea of broken blocks of ice. A dense mess of footprints on the deck evokes images of panicking passengers running in all directions. The bow also resembles the heel of a giant foot sticking out of the water. Both metaphors signal the ultimate decline of any vast man-made structure.

Further on, the ship's deck is littered with remnants of industrial products (pictured above). The steel floor is deteriorating: parts peel off and curve upwards, revealing old newspaper cuttings citing revolutionary slogans and stories of China's engineering miracles. Lining the walls, 30 ink paintings together form a side view of the Nanjing Yangtze River Bridge, an icon of China's industrial development.

In Nation-building Strategy, the hollow corpses of four water buffaloes, each cut in half horizontally, rest on bamboo mats. The lower halves of the bodies are filled with water; bamboo flutes float on the surface. Two iron rails are placed across the top of the installation. The buffalo heads and backs are lined up on the corroded floor, looking as if they are part submerged in water.

The buffaloes symbolize traditional agriculture in China. They are often depicted in idyllic landscape paintings accompanied by farmers playing bamboo flutes. Here, they appear in mutilated form, with railways crushing their backs. The artist expresses how China's rural heritage has been violently sidelined by industrial development.

Qiu is the first Chinese artist living in China to have a large solo exhibition at the Ullens Center for Contemporary Art. The gallery's location, at the heart of the Dashanzi art zone in northeastern Beijing, is pertinent to his work. The art zone grew out of a factory complex, abandoned in the late 1980s, which was part of the 'socialist unification plan' of military-industrial cooperation in the 1950s between China, the former Soviet Union and East Germany.

It is ironic that Qiu's critique of China's development path is displayed in a district threatened by impending destruction as a result of Beijing's urban sprawl.

Jane Qiu writes for Nature from Beijing.

e-mail: jane@janeqiu.com
MADNESS AND MODERNITY

Vienna in 1900 was a place of intellectual tumult, a city at the centre of both psychiatry and modernism. The Wellcome Collection's latest exhibition Madness and Modernity, showing in London until 28 June, explores how ideas of the mind from Sigmund Freud and others influenced views of madness in a period of great change. Fears of living in a modern city created anxieties that resonate today, raising questions about our attitudes to mental illness and its treatment.

http://tinyurl.com/madnessmodernity

\section{FATHER OF ABSTRACTION}

A major retrospective of Wassily Kandinsky's work opened this month at the Centre Pompidou in Paris, running until 10 August. The exhibition probes beyond his popular image as the inventor of abstract painting. It includes watercolours and manuscripts from 1914-17 that were recently rediscovered in his native Russia, and a portfolio from the Bauhaus school that was made for his 60th birthday in 1926. Kandinsky's vivid use of colour - as in his Einige Kreise (1926;

pictured right) - may have been influenced by his experiences of synaesthesia.

\section{http://tinyurl.com/kandinskyparis}

\section{ART OF WORDS}

Language is explored in Tangled Alphabets, an exhibition of work by two South American artists, the Argentinian León Ferrari and the Swiss-born Brazilian painter Mira Schendel. On show at New York's Museum of Modern Art until 15 June, their drawings, sculptures and paintings explore the philosophy of language in visual terms - as the embodiment of voices, words and gestures, and as a metaphor of the human acts of writing and naming.

http://tinyurl.com/moma-tangled

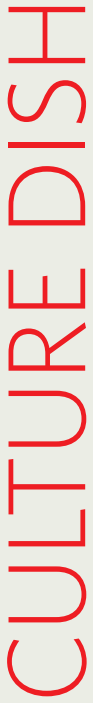

